\title{
Ulusal Gazetelerin Bir Haber Mecrası Olarak Youtube'u Kullanma Biçimlerinin İncelenmesi
}

\section{- İpek TOK}

Dr. Öğr. Üyesi, Bandırma Onyedi Eylül Üniversitesi ikumcuoglu@bandirma.edu.tr ORCID ID: 0000-0002-40190473

\section{ÖZET}

Dijital dünyaya çevrimiçi gazeteler ve haber siteleri ile adım atan ulusal gazeteler, sosyal medyanin öneminin giderek artmasiyla birlikte Facebook, Twitter, Youtube gibi farkl sosyal medya mecralardan da haber paylaşmaya başlamıştır. Bu mecralar içerisinde Youtube, sunduğu firsat ve olanaklar bakımından gazetecilik için giderek daha önemli bir platform hâline gelmektedir. $\mathrm{Bu}$ çalışmanin amact, ulusal gazetelerin Youtube kanallarında paylaştıkları haber videoların inceleyerek Youtube'u kullanma biçimlerini ortaya koymaktır. Çalışma kapsamında, Youtube'da en çok görüntülenen 5 ulusal gazetenin 1-31 Ağustos 2020 tarihinde Youtube'da paylaştığ toplam 554 video içerik analizi yöntemiyle çözümlenmiştir. Çalışmada; gazeteler tarafindan paylaşılan videoların çoğunun televizyon ya da ajansların ürettiği gündem haberlerinden oluştuğu, bu haberlerin, haber kaynağı sesi ile ortam sesi içeren ham görüntüler olduğu ve haber videolarının süresinin 01.00-04.00 dakika aralığında seyrettiği sonuçlarına ulaşılmıştır. Çalışmanın sonuçları ışığında; gazetelerin Youtube'da paylaştığı haber videolarının genel karakteristiğini televizyon ve haber ajanslarindan gelen görüntülerin belirlediği, gazetelerin Youtube'u, televizyon ve ajans haberlerini paylaştıkları bir platform olarak konumlandırdıkları, Youtube'a özel içerik üretmede yetersiz kaldiklarl ve dolaylsiyla Youtube gibi önemli bir mecranin potansiyelini tam olarak kullanamadıkları söylenebilmektedir.

Anahtar Sözcükler: Ulusal Gazeteler, Youtube, Youtube Gazeteciliği, Haber, Haber Videoları. 


\section{Examination of How National Newspapers Use YouTube as}

\section{a News Medium}

\section{- İpek TOK}

Asist. Prof., Bandırma

Onyedi Eylül Üniversitesi

ikumcuoglu@bandirma.edu.tr ORCID ID: 0000-0002-40190473

\begin{abstract}
National newspapers, which have stepped into the digital world with online newspapers and news sites, have started to share news through different social media channels such as Facebook, Twitter, Youtube, with the increasing importance of social media. Among these channels, Youtube is becoming an increasingly important platform for journalism in terms of the opportunities and facilities it offers. The aim of this study is to reveal the ways in which national newspapers use YouTube by examining news videos shared on their Youtube channels. Within the scope of the study, a total of 554 videos shared on August 1-31, 2020 by the 5 most viewed national newspapers on YouTube were analyzed by content analysis method. The results obtained in the study show that most of the videos shared by newspapers consist of television or agency-produced agenda news which are raw footage containing the voice of the news source and the ambient sound, and the duration of the news videos is 01.00-04.00 minutes long. In the light of the results of the study these can be stated that the general characteristic of the news videos that newspapers share on YouTube is determined by footage from television and news agencies, newspapers position YouTube as a platform where they share television and agency news, they are insufficient to produce YouTube-targeted content and therefore they cannot fully use the potential of an important medium such as Youtube.
\end{abstract}

Keywords: National Newspaper, Youtube, Youtube Journalism, Youtube News, News Videos. 


\section{GİRIŞ̧}

Ulusal gazeteler, 1990'l1 yıllarda çevrimiçi gazeteler ve haber siteleri ile internet dünyasına adım atmıştır. 2000'li yıllardan itibaren ise sosyal medyanın yaygınlaşmasıyla gazeteler, haber sitelerinin yanı sıra sosyal medya mecralarından da haber paylaşmaya başlamıştır. 2000'li yıllardan bugüne kadarki süreçte, sosyal medyanın etki alanını çoğalttığı ve bir haber mecrası olarak öneminin giderek arttığı görülmektedir. Facebook, Twitter, Instagram ve Youtube gibi pek çok sosyal medya platformu, gazetelerin haber paylaşımı yaptıkları önemli mecralar arasında yer almaktadır. Bu mecralar içerisinde Youtube'un, hem sunduğu firsatlar ve olanaklar bakımından hem de Türkiye'nin en popüler sosyal medya platformu (We Are Social, 2020) olması bakımından gazetecilik için önemli bir potansiyel taşıdığı söylenebilmektedir. Vatandaşların ve medya organlarının paylaştığı haber videoları ve canlı yayın özelliği ile haberin kullanıcılara anlık olarak ulaşmasını sağlayan popüler ve etkili bir platform olan Youtube'un, gazeteler tarafından kullanılma biçimleri ise üzerinde durulması gereken bir konu olarak karşımıza çıkmaktadır.

Bu noktalardan hareketle çalışmanın temel amacı, ulusal gazetelerin Youtube kanalları üzerinden paylaştıkları haber videolarının temel özelliklerini inceleyerek Youtube’u kullanma biçimlerini ortaya koymaktır. Bu temel amaç doğrultusunda, aşağıdaki araştırma sorularına yanıt aranmıştır:

- Ulusal gazetelerin Youtube kanallarında hangi tür haberler paylaşılmaktadır?

- Ulusal gazetelerin Youtube kanallarında hangi tür videolar paylaşılmaktadır?

- Ulusal gazetelerin Youtube kanallarında paylaştıkları videoların yapısal özellikleri nasıldir?

- Ulusal gazetelerin Youtube kanallarında paylaştıkları videoların içerik özellikleri nasıldır?

- Ulusal gazetelerin Youtube kanallarında paylaştıkları videoların süreleri nasıldır?

Araştırma soruları, aynı zamanda içerik analizi yöntemiyle belirlenen kategorilerin de konularını oluşturmaktadır. Çalışmanın temel amacı ve bu temel amacı aydınlatmaya yönelik olarak ortaya konan araştırma sorularına yanıt bulabilmek amacıyla ilk önce geleneksel medyadan yeni medyaya gazeteciliğin değişen doğası ile ilgili genel bir çerçeve çizilerek sosyal medya ile gazetecilik ilişkisi irdelenecek, daha sonra ise bir haber mecrası olarak Youtube 
üzerinde durulacaktır. Çalışmanın yöntemi ortaya konduktan sonra ise araştırma soruları çerçevesinde elde edilen bulgular yorumlanacaktır.

Yapılan literatür taramasında, Youtube ve gazetecilik üzerine odaklanan çalışmaların genellikle Youtube ve alternatif medya ilişkisi üzerinde yoğunlaştığ1 görülmüştür. Bu nedenle çalışma, Youtube gibi potansiyeli giderek artan bir mecranın, ulusal gazeteler tarafından kullanım biçimlerini ortaya koyması bakımından önemlidir ve literatüre katkı sunması hedeflenmiştir.

\section{KAVRAMSAL ÇERÇEVE}

\subsection{Sosyal Medya ve Gazetecilikte Yaşanan Dönüşümler}

1990’lı yıllarda internetin giderek yaygınlaşması, gazetecilik alanında önemli gelişmeler yaşanmasına neden olmuştur. Bu dönemde, basılı gazeteler yavaş yavaş internet için de içerikler üretmeye başlamıştır. 1992 yılında Chicago Tribune gazetesinin internet sitesi ile 1993 yılında Florida Üniversitesi Gazetecilik Bölümü tarafından yayınlanan gazetenin web sitesi, ilk internet gazeteciliği örnekleri arasında yer almaktadır. 1994 yılında İngiltere'de yayınlanan Daily Telegraph gazetesinin "Electronic Telegraphy" adlı çevrimiçi gazetesi, basılı gazetelerin web sayfalarına aktarılmasının ilk örneğidir. Bu gelişmeyi, 1995 yılında New York Times, The Washington Times, Herald Tribune ve Daily Mirror gibi gazetelerin sayfalarını internete taşımaları takip etmiştir. Türkiye'de ise Milliyet gazetesi 1996 yılında içeriğinin tamamını internet ortamına taşıyan ilk gazete olmuştur. Milliyet gazetesini Hürriyet, Sabah ve Akşam gazeteleri izlemiştir. 2000'li y1llara gelindiğinde ise dünyada olduğu gibi Türkiye'de de basılı gazetelerin dijital versiyonları biçimindeki çevrimiçi gazeteler, internete özgü içeriklerini geliştirerek gelişmiş haber siteleri biçimini almıştır (Tokgöz, 2019, s. 242-243).

2000'li yıllarda sosyal medya ile internet dünyası da önemli değişimler geçirmeye başlamıştır. Sosyal medya; kullanıcı merkezli, etkileşime açık, paylaşıma dayalı, iletişim düzeyi yüksek platformları ifade etmektedir (Dijk, 2016, s. 301-322). İlgilendikleri alanları ve kişisel deneyimlerini farklı insanlarla paylaşmak isteyen kullanıcılar, sosyal ağ siteleri aracılığıyla ilişkiler geliştirerek sosyal medyayı yaratmıştır. Bugün sosyal medya içerisinde; birden fazla internet kullanıcısının birlikte içerik ürettiği sözlükler; bireysel paylaşımlar yapılan bloglar ve Twitter gibi mikroblog siteleri; Instagram, Youtube, Soundcloud gibi fotoğraf, video ve müzik paylaşılan içerik toplulukları; kullanıcıların kişisel profillerini oluşturarak arkadaşları 
ile etkileşime geçebilecekleri Facebook gibi sosyal paylaşım siteleri; LinkedIn gibi iş ağları; kullanıcıların çevrimiçi iletişime geçebilecekleri sanal oyunlar ve Whatsapp, Bip gibi anlık mesajlaşma uygulamaları yer almaktadır (Kaplan \& Haenlein, 2010, s. 59-68).

Paylaşım temelli ve etkileşimli yapısı ile sosyal medya, gazetecilik alanında da önemli gelişmeler yaşanmasına neden olmuştur. Bu süreçte, haber kaynaklarına erişim biçimlerimiz önemli ölçüde değiştirmiştir. Kullanıcılar önceleri sosyal medyayı haberle ilgili video ve fotoğraflara ulaşmak amaciyla ek bir kaynak olarak kullanmıştır (Hermida, 2012, s. 313). Ancak günümüzde sosyal medya, haber almak isteyen kullanıcıların en çok tercih ettiği kaynak konumundadır. Reuters 2020 Dijital Haberler Raporu'na göre; 2020 yılında Türkiye'nin en çok tercih edilen haber mecrası $\% 85^{\prime}$ 'lik oran ile sosyal medyanın da dâhil olduğu internettir. İnternetten sonra habere ulaşmak için en çok tercih edilen ikinci mecra \%68 ile televizyondur. Yazılı basın ise \% 42 'lik oran ile habere ulaşmak için en son tercih edilen mecra durumundadır (Newman, Fletcher, Schulz, And1, \& Nielsen, 2020).

Sosyal medya hem kullanıcılar hem de gazeteciler bakımından önemli bir haber kaynağıdır. Son yıllarda liderlerin, kanaat önderlerinin ve kamuya mal olmuş kişilerin sosyal medya üzerinden yaptıkları açıklamalar sıklıkla haber konusu olmaktadır. Sosyal medya kullanıcılarının paylaştığı video, fotoğraf gibi içerikler veya sosyal medyadaki tartışmalar da gazeteciler için önemli bir veri kaynağıdır. Kullanıcılar için ise sosyal medya, habere erişmenin yanı sıra diğer kullanıcılarla paylaşabilme ve fikir alışverişinde bulunabilme anlamına gelmektedir. Kullanıcılar sosyal medya ile haber üretim sürecine de aktif bir şekilde katılma olanağına kavuşmuştur.

Sosyal medya kullanıcıları, hem medyadan gelen haberleri kendi hesaplarında paylaşmakta hem de meslekleri gazetecilik olmasa da haber yapıp üretebilmektedir. Yurttaş gazeteciliği olarak tanımlanan bu yeni gazetecilik anlayışı, özellikle sosyal medya ile birlikte profesyonel olarak medyada çalışmayan, ancak tanık olduğu olayları haberleştirerek sosyal medyadan paylaşan kullanıcıları ifade etmektedir (Alemdar \& Uzun , 2019, s. 274). Artık yalnızca gazeteciler değil; kullanıcılar da haber üretmektedir. Böylece kullanıcılar, haberin yalnızca tüketicisi değil; gazetecilerle etkileşimi artmış birer haber üreticisi konumuna yerleşmiştir. Kullanıcıların haber üretim sürecine gösterdikleri katılım, gazeteciler ile kullanıcılar arasındaki iş birliklerini artırmaktadır (Çevikel, 2011, s. 66). 
Sosyal medya ile birlikte haber üretiminde ve dağıtımında kullanıcıların rolünün giderek artması, geleneksel okur-gazeteci ilişskisini de değişmiştir. Kullanıcı merkezli bu yeni anlayış, geleneksel medyada; editörler, servis şefleri, sorumlu müdürler gibi eşik bekçilerinin (gate keeper) yer aldığı katı editöryel süreçlerin esnekleşmesine neden olmuştur (Alemdar \& Uzun , 2019, s. 276). Gün içinde birçok haberi Twitter, Instagram, Facebook gibi mecralarda paylaşan medya işletmeleri, takipçileri sayesinde haberi hızlıca dolaşıma sokabilmektedir. Sosyal medya ile birlikte haberlerin kaç kullanıcıya ulaştı̆ğ, hangi haberlerin kaç kullanıcı tarafından paylaşıldığı ve hangi haberlerin sosyal medyanın gündeminde kaldığı gibi sorular önemli hâle gelmiştir. Geleneksel medyada yazı işlerinin sorumluluğunda olan ve okuyucuların müdâhil olamadığı haber seçimi süreci, sosyal medya ile birlikte kullanıcıların tepkilerini daha çok dikkate almaya başlamıştır. Kısacası sosyal medyada ortaya çıkan eğilimler, haber içeriklerini belirlemektedir (Güzel \& Özmen, 2018, s. 212).

Haberlerin giderek daha fazla kullanıc1 odaklı olması, SEO (Search Engine Optimisation $)^{1}$ haberciliğinin gelişmesine neden olmuştur. Haberlerin arama motorlarında üst sıralarda yer alacak biçimde üretilmesi zorunluluğu, $5 \mathrm{~N} 1 \mathrm{~K}$ ya da ters/düz piramit olarak bilinen temel haber yazma ilkelerini değiştirmiştir. Haber trafiğini takip ederek daha fazla kullanıcıya ulaşmayı hedefleyen sosyal medyada habercilik, farklı parametrelerin geçerli olduğu yeni bir sistemi ifade etmektedir.

Sosyal medya, video izlemekten, müzik dinlemeye, mesajlaşmaktan, haber almaya kadar pek çok nedenle kullanılmaktadır (We Are Social, 2020). Türkiye'de internet kullanıcı sayısı Nisan 2019'dan Ocak 2020'ye kadar 3 milyon kişi artarak 62 milyon kişiye ulaşmıştır. Türkiye'de sosyal medyayı aktif olarak kullanan kişi sayısı ise Nisan 2019'dan Ocak 2020'ye kadar 2.2. milyon artarak 54 milyona yükselmiştir. Şekil 1'de Ocak 2020 verilerine göre, Türkiye'nin en popüler sosyal medya platformlarına yer verilmiştir. Buna göre $\% 90$ oran ile Youtube, sosyal medya kullanıcılarının en çok tercih ettiği mecradır.

\footnotetext{
1 Arama motoru optimizasyonu olarak da adlandırılan SEO, arama motorlarının web sitelerini daha kolay taramasını sağlayacak çalışmaları ifade etmektedir. Arama motorları üzerinden ücretsiz trafik kazanmak için yapılan bu çalışmalar, haber sitelerinde de uygulanmaktadır. Haber siteleri, hazırladıkları içerikleri arama trendlerine veya Google arama yönergelerine göre hazırlamaktadır.
} 


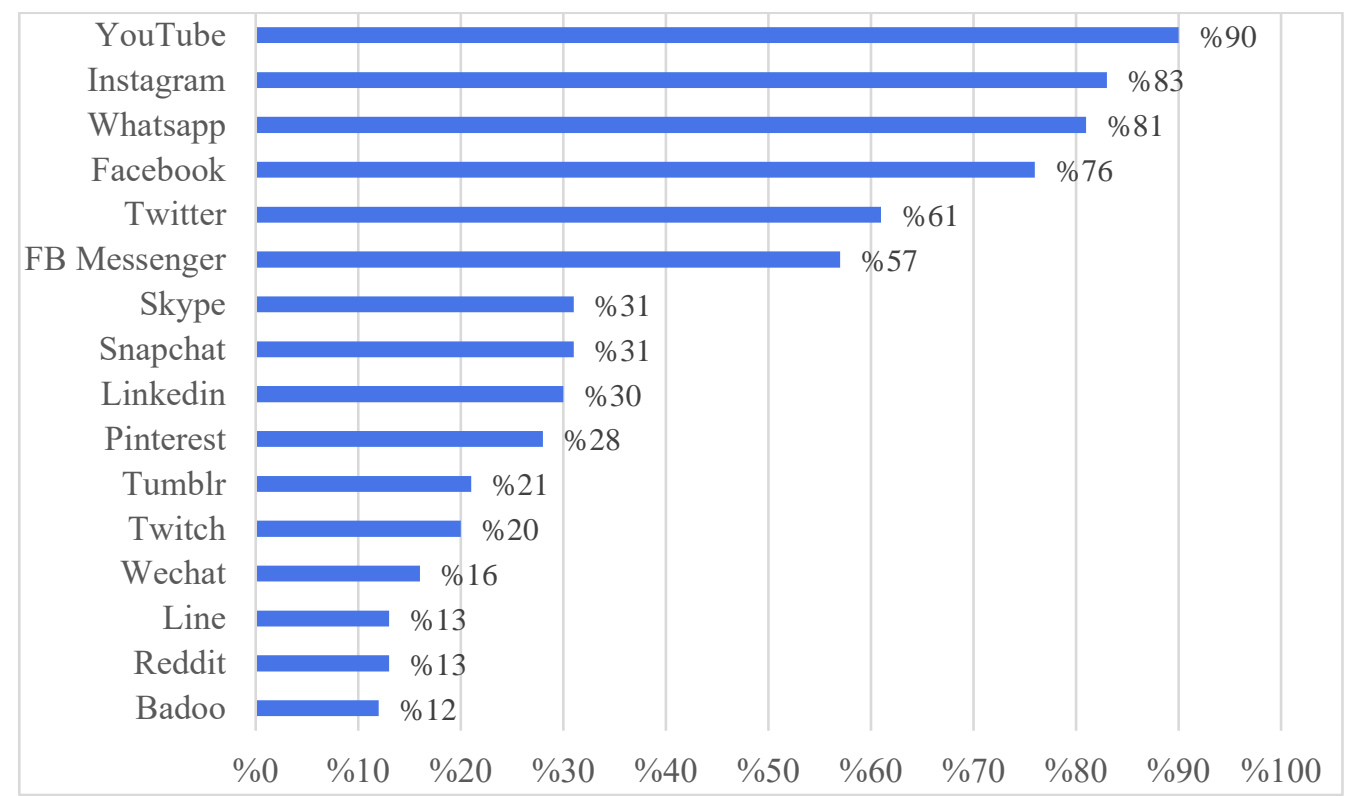

Şekil 1. 2020 yılı Türkiye'nin en popüler sosyal medya platformları (platformları kullandığını belirten kullanıc1 yüzdelerine göre) (We Are Social, 2020).

Türkiye'nin en popüler sosyal medya platformu olan Youtube, video paylaşımına dayanan yapısı ile kullanıcıların en çok tercih ettiği mecra olmuştur. Habere ulaşmak isteyen kullanıcıların sosyal medyayı aktif bir şekilde kullandıkları da düşünülürse Youtube'un ve Youtube'da paylaşılan haber videolarının gazetecilik açısından önemli bir alan olduğunu söylemek mümkündür.

\subsection{Haber Videoları ve Video Habercilik}

Her gün milyonlarca insan; video izlemek, fotoğraf yüklemek, sosyal ağlarda vakit geçirmek, insanlarla etkileşime geçmek ve bilgi edinmek için internet sitelerini ziyaret etmektedir. Kullanıcılar özellikle video ve fotoğraf paylaşarak etkileşime girmekte; bu içeriklere milyonlarca yorum bırakmaktadır. İnternet kullanıcılarının videoları izleme, paylaşma, kaydetme gibi faaliyetler için giderek daha fazla vakit ayırdıkları görülmektedir (Haak, Parks, \& Castells, 2012). Buna göre, 2013 yılında 1 terabayt olan video trafiği, 2018 yılında 11,4 terabayta yükselmiştir. 2020 yılına geldiğimizde ise dijital videoların internet trafiğinin yaklaşık \%80’ini oluşturduğu görülmektedir (Business of Apps, 2020). 
Eğitimden eğlenceye pek çok farklı alanda karşımıza çıkan video, gazetecilik için de önemli bir alandır. Videonun haber için kullanımının köklerinin aslında haber filmlerine kadar gittiği söylenebilir. Savaş dönemlerinde propaganda amaçlı kullanılan haber filmleri, haberin görüntülerle verilmesinin ilk örneklerinden sayılabilir. 1980'li yıllardan itibaren iletişim teknolojilerinde yaşanan gelişmeler ise haberciliği radyo ve televizyon yayınlarının önemli bir aktörü hâline getirmiştir. Bu dönemde, savaş bölgelerinden haber vermenin önemi giderek artmıştır. Uydu teknolojilerinde yaşanan gelişmeler televizyon yayıncılığını geliştirmiştir. 1990’lı yıllarda televizyon yayıncılığının giderek profesyonelleşmesi ve bilgisayar teknolojilerinde yaşanan gelişmeler haberciliği kökten değiştirmeye başlamıştır. Böylece video haberciliği, internetin kullanımıyla birlikte giderek yaygınlaşmış ve haberciliğin önemli bir türü olarak kabul edilmiştir (Koşar, 2015, s. 27).

Video haberciliği ile daha çok, haberin her aşamasında gazetecinin imzasının olduğu bir habercilik biçimi ifade edilmektedir. Tek kişilik orkestra (One man band) olarak da geçen bu habercilik biçiminde haberci, haberin yazımından çekimine, kurgulanmasından sunumuna kadar her aşamasını kendisi hazırlamaktadır. Hafif ve kolay taşınabilir cihazların yaygınlaşması video habercilerinin önünü açmıştır. Haber videoları ile ise haberin video yoluyla aktarılması, kurgulanmış veya ham görüntülerden oluşan videolar akla gelmektedir. Haber videolarında haber, yazarak değil video çekilerek hazırlanmakta, haberin ana kahramanı metin değil; çekilen görüntüler olmaktadır (Bock, 2011, s. 705-718) .

İnternet gazeteciliğinin gelişmesi ile birlikte haber siteleri, haber videolarını aktif bir şekilde kullanmaya başlamıştır. 2006 yılında Amerika'da meydana gelen Katrina Kasırgasının The Washington Post gazetesinin internet sitesinde yayınlanması, 2007'de Youtube ile CNN'in Başkanlık seçimleri için yaptıkları ortaklık ve 2012 yılında video gazetecilerinin kurduğu "Storyhunter" adlı web sitesi, Amerikan medyasında haber videoları ile ilgili gerçekleşen önemli gelişmeler arasında yer almaktadır (Pew Research Center, 2012).

Associated Press'in haber videoları ile ilgili yaptığı araştırmaya göre artık videolar, habere eklenen bir ek değil; haberin kendisi hâline gelmiştir (Associated Press, 2013). Videonun öneminin giderek artması, haber videolarının daha profesyonel biçimde ele alınmasını da zorunlu hâle getirmiştir. Özellikle Amerika ve İngiltere'de medya organizasyonlarında video habercilikle ilgili ayrı birimler oluşturulmaktadır. Wall Street 
Journal, BBC, CNN gibi önemli medya devleri video alanına önem vermektedir. Ülkemizde de özellikle internet medyasında video editörlüğü, video kurgu gibi farklı uzmanlaşma alanları bulunmaktadır. 360 derece video ve Virtual Reality (VR) uygulamaları, haber merkezlerinin artık sıklıkla kullandığı teknolojilerdir. Haber videoları, sosyal medya platformları içerisinde de yaygın olarak kullanılmaktadır. Bu platformlar içerisinde özellikle Youtube, tamamen videoya ve canlı yayınlara dayanan yapısı ile haber videoları için önemli bir mecra konumundadir.

\subsection{Bir Haber Dağıtım Kanalı Olarak Youtube}

2005 yılında kurulan Youtube, profesyonel medyanın sınırlarını yeniden biçimlendiren akılalmaz büyüklükte bir video arşivi olarak tanımlanmaktadır (Burgess \& Green, 2018, s. 14). Google'ın, Youtube'u 2006 yılında 1,65 milyar dolara satın alması, giderek gelişen çevrimiçi videoların yasal bir zemine kavuşması anlamında önemli bir dönüm noktası olmuştur (Business of Apps, 2020).

2006 yılında, yaklaşık 100 milyon videoya karşılık gelen tüm çevrimiçi videoların \%60’1 Youtube üzerinden yayınlanırken, bu oran 2008 yılında \%75'e yükselmiştir (Peer \& Ksiazek, 2011, s. 47). Youtube, 2020 yılı itibarıyla her ay 2 milyar kişinin ziyaret ettiği, günde 5 milyar civarında videonun izlendiği ve her dakika 500 saatlik videonun yüklendiği dev bir platformdur. Youtube'un aylık ziyaretçi sayısı, internetin neredeyse üçte biri kadardır (Youtube, t.y.). Buna göre Youtube, Google'dan sonraki ikinci en popüler internet sitesidir (Alexa, 2020). Türkiye'de de 2019 yılında en çok ziyaret edilen web sitelerine baktığımızda, en popüler video platformu Youtube'un 20.563.398 kişi ile Google'dan sonra en çok kullanıcı tarafından ziyaret edilen internet sitesi olduğu görülmektedir (Digital Age, 2020).

Bir video paylaşım platformu olan Youtube; video yükleme ve izleme dışında, kullanıcılara videolara yorum yapabilme, videoları beğenme ya da beğenmeme ve diğer kullanıcılarla sohbet edebilme gibi olanaklar da sunan etkileşimli bir platformdur. Özellikle son 10 yılda Youtube'a özgü içerikler üreterek ünlenen Youtuber'ların hazırladığı videolarla Youtube, bugün her yaş grubuna hitap etmekte ve geniş kitleler tarafından izlenmektedir (Ying, 2007, s. 16-56). Youtube'da; müzik videolarından, canlı yayınlara, filmlere ve kullanıcıların hazırladığı içeriklere kadar pek çok farklı türde video bulunmaktadır. Youtube, haber videoları için de önemli bir kaynaktır. 
Youtube'un, dünya genelinde gazeteciliği etkilemesinin başlangıcı, vatandaşların ürettiği amatör haber videolarına dayanmaktadır (Santin \& Monzoncillo, 2020, s. 3-4). Doğal afet, kaza, adli vakalar gibi vatandaşların tanıklık ettiği ve cep telefonlarıyla kolay bir şekilde görüntüledikleri olaylar, amatör haber videolarına olan ilgiyi giderek arttırmıştır. Japonya'da 2011 yılında gerçekleşen tsunami felaketini aktaran 20 Youtube videosu, olayı takip eden ilk bir hafta içerisinde yaklaşı 100 milyon kez izlenmiştir. Bu olay, Youtube’un tüm dünyada bir haber mecrası olarak görülmeye başlanmasına neden olmuştur (Pew Research Center, 2012).

Youtube'da "politika ve haberler” kategorisi dikkate alınarak yapılan araştırmaya göre (Pew Research Center, 2012) en hızlı yayılan haber videolarının temel özellikleri şöyledir:

- En popüler haber videoları, doğal afetler ve ani gelişen politik olaylarla ilgili görüntülerin olduğu videolardır.

- Haber videoları, haberin doğası gereği güncelliğini çabuk kaybedebilecek videolardır. Eğlence, oyun vb. video türlerine göre bu bir dezavantaj gibi görünse de haber videoları zaman zaman diğer tüm videolardan daha çok izlenebilmektedir. Japonya'da yaşanan tsunami felaketi, Usame Bin Ladin'in öldürülmesi gibi olaylar, yayınlandıkları zaman Youtube'un en çok izlenen videoları arasında yer almıştır.

- Haber videolarının çekilmesinde vatandaşlar kilit rol oynamaktadır. Youtube'da en çok izlenen videoların \%39'unu vatandaşların çektiği ham görüntüler, \%51'ini ise bir haber kuruluşunun logosunu taşıyan haberler oluşturmaktadır. Böylece, Youtube yurttaş gazeteciliği için önemli bir referans kaynağ 1 hâline gelmektedir.

- Vatandaşlar; sadece haber yaparak değil, haber kuruluşları tarafından yapılan haberleri paylaşarak da haber videolarının daha çok kullanıcıya ulaşmasını sağlamaktadır.

- En popüler haber videoları, ham görüntülerle kurgulanmış görüntülerin birlikte düzenlendiği haber videolarıdır.

- Haber videolarında; kamuya mal olmuş önemli isimlerin bulunması, haberi izletmeye yetecek ana itici güç değildir. Sadece bu kişiler var diye her haber videosu çok izlenmemektedir. 
- TV haberlerinden farklı olarak Youtube'un en popüler videolarının uzunluklarının farklılık gösterdiği görülmektedir. Buna göre, bir TV haber videosu ortalama 1-2 dakika kadarken Youtube'daki haber videolarının uzunluğunun haberin içeriğine göre değiştiği ve geleneksel medyadaki kadar katı kurallar bulunmadığı görülmektedir.

Haber videolarının gün geçtikçe daha popüler hâle gelmesi, Youtube'un önemini giderek artırmaktadır. Dünyada habere ulaşmak için en çok kullanılan sosyal medya platformu Facebook'tur. Facebook’tan sonra ise Youtube gelmektedir. Buna göre dünyada habere erişmek için Youtube kullanım oranları, 2016 yılında \%31, 2017 yılında \%32, 2018 yılında \%41 ve 2019 yılında ise \%49'a yükselmiştir (Newman, Fletcher, Schulz, And1, \& Nielsen, 2020). Daha önce Tablo 2'de verilen bilgilere göre, Youtube Türkiye'de de \%90 gibi yüksek bir oranla en popüler sosyal medya mecrasıdır. Dolayısıyla Türkiye'de Youtube, habercilik açısından gün geçtikçe daha önemli bir mecra hâline gelmektedir.

\section{YÖNTEM}

Ulusal gazetelerin Youtube kanalları üzerinden paylaştıkları haber videolarının temel özelliklerini inceleyerek bir haber mecrası olarak Youtube'u kullanma biçimlerini ortaya koymayı amaçlayan bu çalışmada, içerik analizi yöntemi kullanılmıştır. Sosyal bilimler alanında en sık kullanılan yöntemlerden biri olan içerik analizi, iletişim içeriğinin önceden belirlenmiş temalar çerçevesinde sistematik özetinin yapıldığı bir tekniktir (Geray, 2014, s. 135). İçerik analizi süreci; araştırma probleminin ifade edilmesi, örneklemin belirlenmesi, kategorilerin oluşturulması, kodlama yapılması ve daha sonra ise sonuçların yorumlanması biçiminde gerçekleşmektedir. Özetlemek gerekirse; içerik analizi yöntemi amaçların belirlenmesi ve kavramsallaştırma, tasarım ve planlama, uygulama ve analiz aşamalarından oluşmaktadır (Riffe, 2005, s. 55-56).

Çalışmanın örneklemini, Youtube'da en çok görüntülenen ilk 5 ulusal gazetenin, 1-31 Ağustos 2020 tarihleri arasında Youtube kanallarında paylaştıkları toplam 554 haber videosu oluşturmaktadır. Örneklem seçiminde, gazetelerin abonelik sayıları yerine, görüntülenme sayıları baz alınmıştır. Youtube'da bir kanala abone olmadan da video izlemek mümkündür. Dolayısıyla çalışmada, görüntülenme sayılarının temel alınmasının daha sağlıklı olacağı düşünülmüştür. 
Gazetelerin Youtube kanallarının genel görünümünün verildiği Tablo 1 incelendiğinde, en yüksek görüntülenme sayısına sahip 3. gazetenin Akit gazetesi olduğu anlaşılmaktadır. Ancak çalışmanın örneklemi sadece basılı yayıncılık faaliyeti yapan gazetelerle sınırlandırılmıştır. Bu nedenle basılı yayıncılığın yanı sıra televizyon yayıncılığı da yapan Akit gazetesi çalışmada yer almamış, onun yerine en çok görüntülenen 6. gazete olan Sözcü gazetesi örnekleme eklenmiştir.

Tablo 1. Gazetelerin Youtube Kanallarının Genel Görünümü (03.09.2020 itibarıyla)

\begin{tabular}{|c|c|c|c|c|}
\hline Youtube & Görüntülenme & Abone & Video & Youtube'a \\
\hline Kanalının Adı & Sayısı & Sayısı & Sayısı & Katılma Tarihi \\
\hline Türkiye & 233.584 .101 & $370 \mathrm{~B}$ & 14.143 & 26.07 .2013 \\
\hline Yeni Şafak & 127.182 .842 & $214 \mathrm{~B}$ & 3.860 & 14.06 .2016 \\
\hline Akşam TV & 53.470 .065 & $83.6 \mathrm{~B}$ & 4.216 & 07.11 .2012 \\
\hline Hürriyet.com.tr & 38.044 .015 & $55.1 \mathrm{~B}$ & 3.738 & 20.02.2014 \\
\hline Akit TV & 28.625 .526 & - & 11.017 & 16.02 .2015 \\
\hline Sözcü TV & 23.011.342 & $176 \mathrm{~B}$ & 1.913 & 19.08.2016 \\
\hline Evrensel & 21.610 .117 & $24 \mathrm{~B}$ & 5.826 & 05.05 .2013 \\
\hline Cumhuriyet & 14.804 .476 & $52 \mathrm{~B}$ & 3.422 & 11.05 .2019 \\
\hline Birgün & 6.049 .925 & $15.6 \mathrm{~B}$ & 1.335 & 19.10.2014 \\
\hline Karar TV & 5.660 .191 & $22.4 \mathrm{~B}$ & 668 & 21.05 .2015 \\
\hline Yenibirlik & 4.867.210 & $4.64 \mathrm{~B}$ & 2.921 & 16.01.2017 \\
\hline Yeniçağ & 2.508 .073 & $15.8 \mathrm{~B}$ & 437 & 15.02 .2016 \\
\hline Doğruhaber & 1.858 .302 & $5,36 \mathrm{~B}$ & 3526 & 17.08.2011 \\
\hline Milliyet & 1.832 .259 & - & 684 & 16.01.2020 \\
\hline Aydinlık & 1.641 .421 & $1,9 \mathrm{~B}$ & 674 & 31.03 .2018 \\
\hline Millî gazete & 715.209 & $1,05 \mathrm{~B}$ & 1719 & 18.04 .2020 \\
\hline Diriliş Postası & 651.305 & $5,36 \mathrm{~B}$ & 617 & 16.11.2017 \\
\hline Posta & 614.329 & - & 130 & 29.08.2019 \\
\hline Yeni Mesaj & 322.485 & $3.21 \mathrm{~B}$ & 798 & 13.09.2017 \\
\hline Dünya & 183.433 & $4,59 \mathrm{~B}$ & 235 & 23.11.2019 \\
\hline Milat & 89.328 & - & 100 & 18.08.2018 \\
\hline Türkgün & 2.612 & 393 & 4 & 15.08.2018 \\
\hline Anayurt & 2.160 & 8 & 28 & 02.10 .2011 \\
\hline Yeni Asya & - & - & - & - \\
\hline Korkusuz & - & - & - & - \\
\hline Analiz & - & - & - & - \\
\hline Şok & - & - & - & - \\
\hline
\end{tabular}

Tablo 1'de yer alan gazeteler, Basın İlan Kurumu'nun internet sitesindeki yaygın gazeteler listesine göre seçilmiştir (Basın İlan Kurumu, 2020). Çalışmanın örneklemine dâhil edilen gazetelelerin 1-31 Ağustos 2020 tarihleri arasında Youtube kanallarından paylaştıkları video sayıları ise Tablo 2'de verilmiştir. 
Tablo 2. Gazetelerin Youtube Kanallarında Paylaștıkları Video Sayıları (1-31 Ağustos 2020)

\begin{tabular}{ll}
\hline Youtube Kanalları & Video Sayısı \\
\hline Türkiye & 250 \\
Yeni Şafak & 35 \\
Akşam TV & 203 \\
Hürriyet.com.tr & 46 \\
Sözcü TV & 20 \\
\hline Toplam & $\mathbf{5 5 4}$ \\
\hline
\end{tabular}

İçerik analizi yönteminin temelinde, verilerin küçük birimlere bölünmesi ve bütünün karakteristik özelliklerinin incelenen küçük birimde ortaya çıkarılması yatmaktadır. Bunun için veriler kategorilere ve kategorileri oluşturan değerlere ayrılmaktadır (Gray, 2004, s. 329). Çalışmada; "haber türü”, "video türü", "videoların yapısal özellikleri”, "videoların içerik özellikleri” ve "video süreleri” olmak üzere toplam 5 kategori bulunmaktadır. Bu kategorileri oluşturan alt kategoriler ise Argila (2017, s. 9-10), Bock (2016, s. 500) ve Şen (2020, s. 197 214)'in çalışmaları referans alınarak hazırlanmıştır. Buna göre alt kategoriler aşağıdaki gibidir:

\section{- Haber Türü}

2016 yılında Reuters Institute'un dijital haber araştırmasında, kullanıcıların en çok tercih ettiği haber türleri "Spor", "Ekonomi”, "Politika, Bilim\&Teknoloji”, "Sağlık\&Eğitim”, "Çevre", "Yaşam" ve "Magazin" biçiminde ayrılmıştır (Newman N., Fletcher, \& Nielsen , 2016). Çalışmada, bu haber türleri genişletilerek şu şekilde sıralanmıştır:

Politika: Liderler, politikacılar, siyasi partiler, bürokratlar, mitingler, basın açıklamaları.

Dıș Haberler: Diplomasi, uluslararası ilişkiler.

Ekonomi: İş yaşamı, ekonomi, finans, ticaret.

Bilim-Teknoloji: Bilimsel gelişmeler, keşifler, yeni teknolojiler.

Gündem: Son dakika haberleri, sıcak gelişmeler, kaza, saldırı, suç vs. güncel olaylar.

Yaşam: Günlük hayattan insan hikâyeleri, hayvanlar, eğlenceli-renkli haberler, seyahat.

Kültür-Sanat: Müzik, sinema, sahne sanatları gibi etkinlikler, sanatçılar, kültür dünyası.

Eğitim: Eğitim, öğretim, öğrenciler, öğretmenler.

Sağlık: Sağlık çalışanları, hastaneler, hastalıklar ve tedavi yöntemleri.

Spor: Spor organizasyonları, spor dalları, kulüpler, spor yöneticileri, sporcular.

Çevre: Çevre sorunları, kirlilik, küresel ısınma.

Magazin: Ünlü kişiler, dedikodular, astroloji.

Diğer: Tarih, program tanıtımı vb. 


\section{- Video Türü}

TV/Ajans Haberi: Televizyon kanalı veya haber ajansı logolu ham görüntüler.

Belgesel: Tanıklar, uzmanlar, gazeteciler eşliğinde sunulan, belirli bir konuyu derinlemesine açıklamayı amaçlayan, 4 dakikadan daha uzun süren gazeteci anlatısı.

Star Gazeteci: Bir konuyu esprili bir biçimde ele alarak anlatan, kamuoyunda tanınan ve sevilen ve belli bir takipçi kitlesi olan gazetecilerin çektikleri videolar.

Analiz: Bir veya birden çok gazetecinin, bir konuyu, resmî bir üslupla ele alması ve ayrıntılı biçimde yorumlaması.

Vatandaş kaynaklı haber: Vatandaşların çekip haber kuruluşlarına gönderdiği, bir ajans ya da televizyonun logosunu taşımayan ham görüntüler.

Dosya Haber: Genellikle güncelliğini yitirmeyecek haber konularının anlatıldığı, 4 dakikadan daha kısa süren bilgilendirici haber videoları.

Söyleşi: Derinlemesine analizden çok, sohbet şeklinde geçen söyleşiler.

Sokak röportajı: Belirli bir konu hakkında sokaktaki vatandaşa sorular yöneltilmesi.

Tek kişilik yayın: Ünlü kişi, programcı vb. kişilerin, internet üzerinden yaptıkları tek kişilik yayınlar.

\section{- Videoların Yapısal Özellikleri}

Ham: Görüntü üzerinde düzenleme yapılmamış, kurgulanmamış çekimler.

Kurgulanmış: Kurgulanarak yayına hazır hâle getirilmiş görüntüler.

Canlı yayın: Videonun başlığında “canlı” ibaresinin olduğu, eş zamanlı olarak çekilip kaydedilmiş videolar.

Çevrimiçi video konferans: Kişi ya da kişilerce internet üzerinden yapılan görüntülü ve sesli görüşmeler.

Diğer: Program tanıtımları, reklamlar, o haftanın öne çıkan konularından oluşan kısa haber seçkileri vb.

\section{- Videoların İçerik Özellikleri}

Muhabir görünüyor, sesi var.

Muhabir görünmüyor, sesi var.

Dış ses var.

Haber kaynağının sesi/Ortam sesi var (Açılış, toplantı, trafik, sokak sesi vs.).

Müzik var.

Sunucu/anlatıcı var. 
- Video Süreleri

1-30 sn. aras1

31 sn. $-1.00 \mathrm{dk}$. aras 1

$1.01-4.00 \mathrm{dk}$. aras 1

4.01-10.00 dk.

$10.00 \mathrm{dk}$. ve üzeri

\section{BULGULAR}

Çalıșmanın bu bölümünde, araștırma sorularına yanıt bulmak amacıyla yapılan içerik analizinin sonucunda elde edilen bulgular yorumlanacaktır.

\subsection{Haber Türü}

Bu bölümde, ilk önce gazetelerin Youtube kanallarında paylaştıkları videoların haber türlerine göre dağılımına yer verilecek daha sonra ise haber türlerinin gazetelere göre dağılımları ortaya konacaktır. Buna göre, paylaşılan videoların haber türleri, Tablo 3'te sunulmaktadir.

Tablo 3. Haber Türlerinin Genel Dağılımı

\begin{tabular}{lll}
\hline Haber Türü & Haber Sayısı & Oran \% \\
\hline Politika & 79 & 14,2 \\
Diş Haberler & 16 & 2,9 \\
Ekonomi & 24 & 4,3 \\
Bilim-Teknoloji & 1 & 0,2 \\
Gündem & 273 & 49,3 \\
Yaşam & 90 & 16,3 \\
Kültür-Sanat & 7 & 1,2 \\
Eğitim & 1 & 0,2 \\
Sağlık & 8 & 1,4 \\
Spor & 20 & 3,6 \\
Çevre & 1 & 0,2 \\
Magazin & 13 & 2,4 \\
Diğger & 21 & 3,8 \\
\hline Toplam & $\mathbf{5 5 4}$ & $\mathbf{1 0 0}$ \\
\hline
\end{tabular}

Ulusal gazetelerin Youtube'da paylaştığı haberlerin yaklaşık yarısını $(\% 49,3)$ gündem haberleri oluşturmaktadır. Gündem haberlerinin ardından, \%16,3 ile yaşam ve \%14,2 ile politika haberleri gelmektedir. En az paylaşılan haberler ise sağlık $(\% 1,4)$ ve kültür-sanat $(\% 1,2)$ kategorisindedir. Bilim-teknoloji, eğitim ve çevre haberleri ise yalnızca $1 \mathrm{kez}(\% 0,2)$ paylaşılmıştır. Söz konusu durum, gazetelerin Youtube'daki haber üretiminin belirli türlerle 
sınırlı olduğu şeklinde yorumlanabilmektedir. Gündem, yaşam ve politika gibi konularda daha fazla haber üretilmektedir. Sağlık, kültür-sanat, bilim-teknoloji, eğitim ve çevre gibi daha spesifik alanlarda ise haber üretimi oldukça sınırlıdır. Haber türlerinin gazetelere göre dağılımına ilişkin bulgulara Tablo 4'te yer verilmiştir.

Tablo 4. Haber Türlerinin Gazetelerin Youtube Kanallarına Göre Dağılımı

\begin{tabular}{llllll}
\hline Haber Türü & Türkiye & Yeni Şafak & Akşam & Hürriyet & Sözcü \\
\hline Politika & 49 & 2 & 21 & 2 & 5 \\
Diş haberler & - & 5 & 8 & 3 & - \\
Ekonomi & 8 & 1 & 11 & - & 4 \\
Bilim-Teknoloji & - & - & - & 1 & - \\
Gündem & 145 & 18 & 96 & 10 & 4 \\
Yaşam & 28 & 2 & 52 & 8 & - \\
Kültür-Sanat & - & - & - & 1 & 1 \\
Eğitim & 1 & - & - & - & - \\
Sağlık & 7 & - & - & 1 & - \\
Spor & 10 & - & - & 2 & - \\
Çevre & 1 & - & 2 & - & - \\
Magazin & 1 & 7 & - & - & - \\
Diğger & - & $\mathbf{3 5}$ & $\mathbf{2 0 3}$ & $\mathbf{4 6}$ & $\mathbf{2 0}$ \\
\hline Toplam & $\mathbf{2 5 0}$ & & &
\end{tabular}

250 video ile Youtube'da en çok video paylaşan ulusal gazete olan Türkiye gazetesinin yüklediği videoların 145'i gündem haberlerinden oluşmaktadır. Türkiye gazetesi; dış haberler, bilim teknoloji ve kültür-sanat haberlerine hiç yer vermemiştir. Eğitim, çevre ve magazin haberleri ise $1 \mathrm{kez}$ yayınlanmıştır. Yeni Şafak gazetesinde paylaşılan 35 videodan 18'ini gündem haberleri oluşturmaktadır. Bilim-teknoloji, kültür-sanat, eğitim, sağlık, spor, çevre ve magazin haberine yer verilmezken; ekonomi haberi ise 1 kez paylaşılmıştır. Akşam gazetesinin Youtube kanalı da Türkiye ve Yeni Şafak gazeteleri gibi en çok gündem haberlerine yer vermiştir. Buna göre Akşam'ın paylaştığ1 203 videodan 96'sı gündem haberidir. Bilimteknoloji, eğitim, sağlık ve çevre konulu haberlere yer vermeyen gazete; 2 kez magazin haberi paylaşmıştır. Hürriyet gazetesi ise diğer gazetelerden farklı olarak 18 haber ile en çok magazin haberi paylaşan gazete olmuştur. Hürriyet gazetesi; ekonomi, eğitim ve çevre haberlerine yer vermemiştir. Bilim-teknoloji ve sağlık haberi ise 1 kez paylaşılmıştır. Sayıca az olsa da bilimteknoloji haberlerine yer veren tek gazete, Hürriyet gazetesidir. Toplam video sayıs 20 olan Sözcü gazetesi ise 6 haber ile en çok diğer kategorisinde kodlanan haberleri paylaşmıştır. Buna karş1lık gazete, 1 haber ile en az kültür-sanat kategorisinde paylaşım yapmıştır. 


\subsection{Video Türü}

$\mathrm{Bu}$ bölümde, gazetelerin Youtube kanallarında paylaştıkları video türlerine ve video türlerinin gazetelere göre dağılımlarına yer verilecektir. Buna göre, paylaşılan videoların türleri, Tablo 5'te sunulmaktadir.

Tablo 5. Video Türlerinin Genel Dağılımı

\begin{tabular}{lll}
\hline Video Türüi & Haber Sayısı & Oran \% \\
\hline TV/Ajans haberi & 440 & 79.4 \\
Belgesel & 10 & 1,8 \\
Star gazeteci & - & - \\
Analiz & 29 & 5,2 \\
Vatandaş kaynaklı haber & 6 & 1,1 \\
Dosya haber & 37 & 6,7 \\
Söyleşi & 14 & 2,5 \\
Sokak röportaji & 7 & 1,3 \\
Tek kişilik yayın & 11 & 2 \\
\hline Toplam & $\mathbf{5 5 4}$ & $\mathbf{1 0 0}$ \\
\hline
\end{tabular}

Gazetelerin Youtube kanallarında paylaştığı videoların önemli bir çoğunluğu $(\% 79,4)$ TV/ajans haber videolarından oluşmaktadır. Diğer video türleri, geriye kalan \%20’lik pay içerisinde oldukça sınırlı sayıda paylaşılmıştır. Gazetelerin en çok paylaştığı ikinci haber videosu türü; \%6,7 oran ile dosya haber, \%5,2 ile ise analiz videolarıdır. Star gazeteci kategorisinde ise hiç video paylaşılmamıştır. Bu durum, gazetelerin genellikle aynı tür videolar paylaştığını, video türleri arasında dengeli bir dağılım olmadığını göstermektedir. Haber videolarının gazetelere göre dağılımı ise Tablo 6' da verilmiştir.

Tablo 6. Video Türlerinin Gazetelerin Youtube Kanallarına Göre Dağılımı

\begin{tabular}{|c|c|c|c|c|c|}
\hline Video Türüi & Türkiye & Yeni Şafak & Akşam & Hürriyet & Sözcü \\
\hline TV/Ajans haberi & 250 & 1 & 171 & 18 & - \\
\hline Belgesel & - & 6 & 1 & 1 & 2 \\
\hline Star gazeteci & - & - & - & - & - \\
\hline Analiz & - & 5 & 20 & 2 & 2 \\
\hline Vatandaş kaynaklı haber & - & - & 6 & - & - \\
\hline Dosya haber & - & 23 & 1 & 9 & 4 \\
\hline Söyleşi & - & - & 4 & 9 & 1 \\
\hline Sokak röportaj1 & - & - & - & - & 7 \\
\hline Tek kişilik yayın & - & - & - & 7 & 4 \\
\hline Toplam & 250 & 35 & 203 & 46 & 20 \\
\hline
\end{tabular}

TV/Ajans haberlerine en çok yer veren gazeteler; Türkiye ve Akşam gazeteleridir. Türkiye gazetesinin paylaştığı videoların hepsi, Akşam gazetesinin ise toplamda paylaştığı 203 haberin 171 tanesi TV/ajans haberidir. Hürriyet gazetesinin de paylaştığ 46 videonun 18'i TV/Ajans kaynaklıdır. Yeni Şafak gazetesinde, TV/ajans haberleri 1 kez paylaşılırken; dosya 
haber kategorisinde 23, belgesel kategorisinde ise 6 haber paylaşılmıştır. Yeni Şafak gazetesinin TV/ajans haberleri yerine daha çok özgün videolar paylaştığı görülmektedir. Sokak röportajlarına yer veren tek gazete Sözcü gazetesidir. Gazetenin yayınladığı 20 videodan 7'sini sokak röportajları oluşturmaktadır. TV/ajans haberi ise hiç paylaşılmamıştır. Bu durumda, Sözcü gazetesinin de Yeni Şafak gazetesi gibi daha çok özgün içerikler ürettiği söylenebilir. Hürriyet gazetesinde tek kişilik yayınların daha fazla yer aldığı gözlenmiştir. Vatandaş kaynaklı haberlere ise 6 haberle yalnızca Akşam gazetesinde rastlanmıştır.

\subsection{Videoların Yapısal Özellikleri}

$\mathrm{Bu}$ bölümde, gazetelerin Youtube kanallarında paylaştıkları videoların yapısal özelliklerine ve bu özelliklerin gazetelere göre dağılımına yer verilecektir. Buna göre, paylaşılan videoların yapısal özellikleri, Tablo 7'de sunulmaktadır.

Tablo 7. Videoların Yapısal Özelliklerinin Genel Dağglımı

\begin{tabular}{lll}
\hline Videoların Yapısal Özellikler & Haber Sayısı & Oran \% \\
\hline Ham & 421 & 76 \\
Kurgulanmış & 69 & 12,5 \\
Canlı yayın & 13 & 2,3 \\
Çevrimiçi video konferans & 45 & 8,1 \\
Diğer & 6 & 1,1 \\
\hline Toplam & $\mathbf{5 5 4}$ & $\mathbf{1 0 0}$ \\
\hline
\end{tabular}

Elde edilen veriler, gazetelerin paylaştığı videoların çoğunluğunun (\%76) ham görüntülerden oluştuğunu göstermektedir. Söz konusu durumun, TV/Ajans haberlerinin çoğunlukta olmasından kaynaklandığı düşünülmektedir. Haberlerin \%12,5'i ise televizyonda yayınlanmaya hazır hâle getirilmiş TV haberlerinden, stüdyoda çekilen programlardan, öyküleştirilmiş içeriklerden ve derleme dosya haberlerden oluşan kurgulanmış videolardır. Kodlamalar sırasında bazı gazete kanallarında "canlı" ibaresi olan videolara rastlandığı için bu tür videolar canlı yayın kategorisinde kodlanmıştır. Videoların \%2,3’ünü oluşturan canlı yayınlar, özellikle gündem ve politika türünde haberler içermektedir. Çevrimiçi video konferans kategorisi ise videoların \%8,1'ini oluşturmaktadır. Çevrimiçi video konferansların, özellikle Covid-19 pandemisi nedeniyle yaşanan karantina koşullarında, medyanın sıklıkla tercih ettiği bir kaynak hâline geldiği söylemek mümkündür. Videoların yapısal özelliklerinin gazetelerin Youtube kanallarına göre dağılımı ise Tablo 8'de verilmiştir. 
Tablo 8. Videoların Yapısal Özelliklerinin Gazetelerin Youtube Kanallarına Göre Dağılımı

\begin{tabular}{llllll}
\hline Videoların Yapısal Öz. & Türkiye & Yeni Şafak & Akșam & Hürriyet & Sözcü \\
\hline Ham & 231 & 1 & 164 & 18 & 7 \\
Kurgulanmış & 12 & 32 & 4 & 12 & 9 \\
Canlı yayın & 2 & - & 11 & - & - \\
Çevrimiçi video konferans & 5 & 2 & 21 & 13 & 4 \\
Diğer & - & - & 3 & 3 & - \\
\hline Toplam & $\mathbf{2 5 0}$ & $\mathbf{3 5}$ & $\mathbf{2 0 3}$ & $\mathbf{4 6}$ & $\mathbf{2 0}$ \\
\hline
\end{tabular}

Türkiye gazetesi 231 haberle, Akşam gazetesi ise 164 haberle ham görüntüleri en çok kullanan gazeteler olmuştur. Hürriyet gazetesi de 18 haberle en çok ham görüntüler kullanmıştır. $\mathrm{Bu}$ gazetelerin TV/ajans haberlerini en çok kullanan gazeteler oldukları düşünülürse, paylaş1lan TV/ajans haberlerinin ham görüntülerden oluştuğu söylenebilmektedir. Kurgulanmış videolar ise dosya haber ve belgeselin en çok üretildiği gazete olan Yeni Şafak’ta ve dosya haber ile sokak röportajlarının en çok kullanıldığ 1 Sözcü gazetesinde yer almaktadır. Canlı yayın ibareli videolar ise yalnızca Türkiye ve Akşam gazetelerinde kullanılmıştır. Çevrimiçi video konferans ile reklam, tanıtım ve haftalık kısa haber seçkilerinin kodlandığ diğer kategorisine ise en çok Hürriyet ve Akşam gazetelerinde rastlanmıştır.

\subsection{Videoların İçerik Özellikleri}

Bu bölümde, ilk önce gazetelerin Youtube kanallarında paylaştıkları videoların içerik özelliklerine yer verilecek, daha sonra ise video içeriklerinin gazetelere göre dağılımı ortaya konacaktır. Buna göre, paylaşılan videoların içerik özellikleri, Tablo 9'da sunulmaktadır.

Tablo 9. Videoların İçerik Özelliklerinin Genel Dağılımı

\begin{tabular}{lll}
\hline Videoların İçerik Ö. & Haber Sayısı & Oran \% \\
\hline Muhabir görünüyor/Sesi var & 9 & 1,6 \\
Muhabir görünmüyor/Sesi var & 158 & 28,5 \\
Diş ses var & 41 & 7,4 \\
Haber kaynağı sesi/Ortam sesi var & 272 & 49,1 \\
Müzik Var & 5 & 0,9 \\
Sunucu/anlatıcı var & 69 & 12,5 \\
\hline Toplam & $\mathbf{5 5 4}$ & $\mathbf{1 0 0}$ \\
\hline
\end{tabular}

Haber videolarının yaklaşı yarısı (\%49) haber kaynağı sesi/ortam sesi içerikli videolardan oluşmaktadır. Haber videolarının \%28,5'inde ise muhabir görünmemekte yalnızca sesi duyulmaktadır. Muhabirin sadece sesinin değil, kendisinin de göründüğü videolar \%1,6 oranında kullanılmıştır. Dolayısıyla, paylaşılan haber videolarına bakıldığında, muhabir görünürlüğünün neredeyse hiç olmadığı söylenebilmektedir. Haber videosunda bir sunucu/anlatıcının yer aldığı içerikler ise \%12,4 oranında kullanılmıştır. Paylaşılan videoların 
\%7,4'ünde dış ses bulunmaktadır. Dış sesin, özellikle özgün içerikli dosya haberlerde kullanıldığını söylemek mümkündür. Videoların içerik özelliklerinin gazetelere göre dağılımı Tablo 10'da yer almaktadır.

Tablo 10. Videoların İçerik Özelliklerinin Gazetelerin Youtube Kanallarına Göre Dağılımı

\begin{tabular}{llcccc}
\hline Videoların İçerik Ö. & Türkiye & Yeni Şafak & Akșam & Hürriyet & Sözcü \\
\hline Muhabir görünüyor/Sesi var & 4 & - & 1 & - & 4 \\
Muhabir görünmüyor/Sesi var & 71 & 1 & 75 & 8 & 3 \\
Dişs ses var & 5 & 26 & 8 & 1 & 1 \\
Haber k. sesi/ Ortam sesi var & 163 & 1 & 92 & 16 & - \\
Müzik var & 2 & 1 & 2 & - & - \\
Sunucu/Anlatıcı var & 5 & 6 & 25 & 21 & 12 \\
\hline Toplam & $\mathbf{2 5 0}$ & $\mathbf{3 5}$ & $\mathbf{2 0 3}$ & $\mathbf{4 6}$ & $\mathbf{2 0}$ \\
\hline
\end{tabular}

Muhabirin göründüğü videolara yalnızca Türkiye ve Akşam gazetelerinde yer verilmiştir. Ancak Türkiye gazetesinde 4, Akşam gazetesinde 1 olan bu sayı, oldukça azdır. Bunların dışında kalan gazetelerde muhabir görünmemekte, yalnızca sesi duyulmaktadır. Türkiye, Akşam ve Hürriyet gazeteleri en çok haber kaynağının sesi/ortam sesi kategorisinde yer alan videolar paylaşmıştır. Söz konusu durumun, bu üç gazetenin de yoğun bir biçimde TV/ajans haberi kullanması ile ilişkili olduğu söylenebilmektedir. Hürriyet gazetesi en çok sunucu/anlatıcı bulunan haber videoları paylaşmıştır. Yeni Şafak gazetesi ise dış sesi en çok kullanan gazetedir. Bunun nedeni, gazetenin dosya haber ve belgesellerinde diş ses kullanmasıdır.

\subsection{Videoların Süresi}

$\mathrm{Bu}$ bölümde, ilk önce gazetelerin Youtube kanallarında paylaştıkları videoların sürelerine yer verilecek, daha sonra ise video sürelerinin gazetelere göre dağılımı ortaya konacaktır. Buna göre, paylaşılan videoların süreleri, Tablo 11'de sunulmuştur.

Tablo 11. Video Sürelerinin Dağılımı

\begin{tabular}{lll}
\hline Video Süresi & Haber Sayısı & Oran \% \\
\hline $0-30$ sn. & 14 & 2,5 \\
31 sn.-1 dk. & 14 & 2,5 \\
$1.01-4.00 \mathrm{dk}$. & 249 & 45 \\
$04.01-10.00 \mathrm{dk}$. & 206 & 37 \\
$10.01 \mathrm{dk}-.$. & 71 & 13 \\
\hline Toplam & $\mathbf{5 5 4}$ & $\mathbf{1 0 0}$ \\
\hline
\end{tabular}

En çok paylaşılan videolara bakıldığında, videoların \%45'inin 1.01-4.00 dk. aralığında, \%37'sinin ise 4.01-10.00 dk. aralığında olduğu görülmektedir. Paylaşılan videoların \%13'ü 10 dakikadan uzun süreli videolar olurken; 0-30 saniye ve $31 \mathrm{sn} .-1 \mathrm{dk}$. aralığındaki videolar \%2,5 
oranında paylaşılmıştır. 1.01-4.00 dakikalık videoların TV/ajans kaynakı1; 4.01-10.00 dk. ve 10 dakikadan daha uzun süren videoların ise dosya haber, analiz, belgesel, söyleşi ve çevrimiçi video konferans gibi haber videoları olduğunu söylemek mümkündür. Video sürelerinin gazetelere göre dağılımı Tablo 12'de verilmiştir.

Tablo 12. Video Sürelerinin Gazetelerin Youtube Kanallarına Göre Dağılımı

\begin{tabular}{llllll}
\hline Video Süresi & Türkiye & Yeni Şafak & Akșam & Hürriyet & Sözcü \\
\hline $0-30$ sn. & 3 & - & 11 & - & - \\
$31 \mathrm{sn}-1.00 \mathrm{dk}$. & 2 & 1 & 11 & - & - \\
$1.01 .-4.00 \mathrm{dk}$. & 119 & 12 & 97 & 16 & 5 \\
$4.01 .-10.00 \mathrm{dk}$. & 97 & 18 & 66 & 13 & 12 \\
$10.01 \mathrm{dk}-.$. & 29 & 4 & 18 & 17 & 3 \\
\hline Toplam & $\mathbf{2 5 0}$ & $\mathbf{3 5}$ & $\mathbf{2 0 3}$ & $\mathbf{4 6}$ & $\mathbf{2 0}$ \\
\hline
\end{tabular}

Gazeteler en çok 1.01-4.00 dakikalık videolar paylaşmıştır. Bu videoların ardından ise 4.01-10.00 dakikalık videolar gelmektedir. En az paylaşılan videolar ise 0-30 sn. ve $31 \mathrm{sn} .-1$ dk. aralığındaki kısa videolardır. Süresi 10 dakikayı aşan videolara en fazla yer veren gazeteler ise Türkiye, Akşam ve Hürriyet gazeteleri olmuştur. Türkiye ve Akşam gazetelerinin gündem kategorisinde yer alan ve canlı ibaresi bulunan haber videoları ile Hürriyet gazetesinin tanınmış kişilerle yaptığı magazin içerikli söyleşileri ve Akşam gazetesinin analiz videoları 10 dakikayı aşmaktadır.

\section{SONUÇ}

Sosyal medyanın potansiyeli fark edildikçe geleneksel medyanın temel aktörlerinden olan basılı gazeteler de sosyal medya mecralarında yer almaya başlamıştır. 1990'lı yıllardan itibaren çevrimiçi gazeteler ve haber siteleri ile internete adım atan gazeteler, daha sonra Facebook, Twitter, Instagram ve Youtube gibi sosyal medya paltformlarında hesaplar oluşturarak haber paylaşmaya başlamıştır. Bu mecralar içerisinde Youtube, Türkiye'de en çok kullanılan sosyal medya platformu olması bakımından dikkat çekmektedir. Eğlenceden eğitime kadar pek çok alanda video yayınlayan Youtube, son y1llarda habere ulaşmak için de kullanılmaya başlanan etkili bir mecra konumuna gelmiştir.

Ulusal gazetelerin Youtube kanalları üzerinden paylaştıkları haber videolarının temel özelliklerini inceleyerek Youtube'u kullanma biçimlerini ortaya koymayı amaçlayan bu çalışmada; Youtube üzerinden en çok gündem konulu, televizyon veya haber ajansı kaynaklı; 
ham, sadece haber kaynağının sesi ya da ortam sesinin duyulduğu, 1.01-4.00 dakikalık haber videolarının paylaşıldığı sonucuna ulaşılmıştır.

Buna göre, paylaşılan haberlerin türlerine bakıldığında, gazetelerin paylaştığı videoların hemen hemen yarısının gündem kategorisindeki haberlerden oluştuğu görülmektedir. Gündem haberlerinden sonra ise en çok politika ve yaşam konulu haberler paylaşılmıştır. En az paylaşılan haber türleri ise çevre, eğitim ve bilim-teknoloji haberleridir. Gündem kategorisindeki haberler, toplamda paylaşılan haberlerin \% 49,2 'lik oranla yaklaşık yarısını oluşturmaktadır. En yüksek video sayısına sahip olan Türkiye ve Akşam gazetelerinde de paylaşılan haberlerin yarısı gündem konulu haberlerdir. Televizyon haberleri ile ajans haberlerinin o gün yaşanan olaylara odaklanan, güncel gündem haberleri olması beklenmektedir. Çalışmada, son aylarda hayatımızı derinden etkileyen Covid-19 pandemisi ile ilgili haberler de genelde "son dakika", "gündem”, "sıcak gelişme” gibi etiketlerle paylaşıldığı için gündem kategorisi içerisinde değerlendirilmiştir. Covid-19 pandemisi nedeniyle eğitim ve sağlık alanında yaşanan gelişmeler düşünüldüğünde; bu alandaki özel haberlerin azlığının dikkat çekici olduğunu söylemek mümkündür.

Gazetelerin paylaştı̆̆ haber videolarının türlerine bakıldığında, araştırmanın yapıldığı bir aylık süre boyunca paylaşılan videoların yaklaşık \%80'inin televizyon veya haber ajanslarından gelen haberlerden oluştuğu görülmüştür. TV/ajans haberlerini sırasılyla dosya haberler ve analiz haberleri izlemektedir. Dosya haber videolarına en çok Yeni Şafak gazetesi, analiz videolarına ise en çok Akşam gazetesi yer vermiştir. TV/ajans haberlerini en çok kullanan gazeteler, video çoğunluğuna da sahip olan Türkiye ve Akşam gazeteleri olurken dosya haberler en çok Yeni Şafak gazetesi tarafından kullanılmıştır.

Türkiye, Akşam ve Hürriyet gazetelerinin sahiplik yapıları ile bu gazetelerin paylaştığı haber videolarının türleri arasında bir ilişki kurmak mümkündür. Buna göre; Türkiye, Akşam ve Hürriyet gazetelerinin içinde olduğu medya grupları bünyesinde, televizyon ve haber ajansı da bulunmaktadır. Dolayısıyla, bu gazeteler, TV ve ajans haberlerine daha kolay ulaştıkları ve haber görüntülerini internette de paylaşmak istedikleri için bu haberlere sıkça yer vermektedirler. Türkiye gazetesi; İhlas Haber Ajansı (İHA), TGRT Haber ve TGRT Radyo'nun yer aldığı İhlas Holding'in çatısı altında faaliyet gösteren bir yayın kuruluşudur. Akşam gazetesi ise Star ve Güneş gazeteleri ile 24 TV, TV360 ve TV4 kanallarının sahibi olan TürkMedya Grubu'nun içerisinde yer almaktadır. TV/ajans haberlerini en çok paylaşan üçüncü gazete olan Hürriyet gazetesi de bünyesinde Demirören Haber Ajansı (DHA), CNN Türk, 
Kanal D gibi televizyon kanallarını bulunduran Demirören Holding'in medya grubuna dâhildir. Sahiplik yapısı bakımından benzerlik taşıyan bu üç gazete de kendi televizyon ve haber ajanslarından gelen haber videolarını Youtube' da yoğun biçimde kullanmaktadır.

$\mathrm{Bu}$ üç gazeteyle sahiplik yapısı anlamında benzerlik taşıyan ve Albayrak Holding içerisinde yer alan Yeni Şafak gazetesi ise TV/ajans haberlerine sadece bir kez yer vermiştir. Yeni Şafak gazetesine bakıldığında, TV/ajans haberlerinden çok; Youtube için özel hazırlanan tarih, dış politika, vb. konulu dosya haber ve belgesel içerikleriyle öne çıktığı görülmektedir. Yeni Şafak gazetesinin video sayısının az olmasına rağmen görüntülenme sayısının yüksek olması, kullanıcıların Youtube'a özel içerikleri daha çok tercih ettiği biçiminde yorumlanabilir. Yeni Şafak gazetesi, televizyon kanalına da sahip olan bir medya grubunun içerisinde yer almış olmasına rağmen ağırlıklı olarak dosya haberler paylaşmayı tercih etmiştir. Dolayısıyla, sahiplik yapısı kadar gazetelerin haber paylaşımı bakımından Youtube'u nasıl konumlandırdıklarının da önemli olduğu ortaya çıkmaktadır. Gazetelerin Youtube kanallarından paylaştığı haberlere bakıldığında, vatandaş kaynaklı haberlerin ise neredeyse hiç kullanılmadığı ortaya çıkmıştır. Buradan hareketle, Youtube'un habercilikle kesiştiği alan olarak belirtilen vatandaş kaynaklı haberlerin, ulusal gazetelerin Youtube'u kullanma pratikleri içerisinde etkisiz kaldığını söylemek mümkündür.

Haber videolarının yapısal özelliklerine bakıldığında ise neredeyse \%80'lik bir oranla ham görüntülerin çoğunlukta olduğu görülmüştür. Ham görüntülerden sonra ise en çok kurgulanmış görüntülere ve çevrimiçi video konferanslara rastlanmıştır. Ajanstan televizyona gelen haberler, bültenin zaman planlamasına göre kısaltılmalı ve bir anlatıcının sesi eşliğinde hazırlanarak yayına hazır hâle getirilmelidir. Bu nedenle ajanslar, haber kaynağının sesi/ortam sesine müdahale etmeden ham görüntüleri televizyona aktarmaktadır. Youtube' da yayınlanan haber videolarının \%80'inin TV/ajans haberlerinden oluştuğu düşünüldüğünde, ham görüntülerin neden çoğunlukta olduğu sorusu da cevaplanabilmektedir. Ham görüntülere, TV/ajans haberlerini en çok kullanan gazeteler olan Türkiye ve Akşam gazetelerinde rastlanmıştır. Kurgulanmış görüntüler ise en çok Yeni Şafak gazetesinin dosya haber ve belgesel videolarında kullanılmıştır. Çevrimiçi video konferansların ise yaygın bir şekilde kullanıldığ1 gözlenmiştir. Çevrimiçi video konferanslar, Covid-19 pandemisi nedeniyle yaşanan karantina sürecinin sonucunda yaygın bir şekilde kullanıldığı söylenebilir. İnternet bağlantıları; söyleşi, analiz, tek kişilik yayın biçiminde görülmüştür. 
Haber videolarının içerik özelliklerine bakıldığında, paylaşılan videoların neredeyse yarısında haber kaynağının sesi/ortam sesi, olduğu gibi verilmiştir. $\mathrm{Bu}$ durum, haber videolarında ham TV/ajans görüntülerinin kullanılmasının bir etkisi olarak açıklanabilmektedir. Haberlerde muhabirin görünmediği sadece sesinin olduğu videolar ise toplam video sayısının \%28,5'ini oluşturmaktadır. Muhabir görünürlüğünün az olması ve gazetecilerin sadece ses olarak varlık göstermesi ajans haberlerinin yoğun kullanımı ile açıklanabilir. Ancak burada asıl üzerinde durulması gereken konu; muhabirlerin, internet gazeteciliği, sosyal medya ve Youtube gazeteciliği ekseninde zayıflayan rolleridir.

Gazetelerin paylaştığı haber videolarının sürelerine bakıldığında ise, videoların yaklaşık yarısının 1.01-4.00 dk. aralığında olduğu görülmüştür. Bu süreler, videoların \%80’ini oluşturan TV/ajans haberlerinin süreleri kadardır. Çünkü TV/ajans haberlerinin kısa olması, haber bültenine yetişmesi beklenen videoların kurgusunun daha hızlı bir şekilde yapılması için gereklidir. Buna karşıllı, 1.01-4.00 dk. arasında süren videoların, bir konuyu derinlemesine ele alabilmek için yetersiz kaldığı söylenebilir. Nitekim videoların \%37'sini oluşturan 4.01-10.00 dakikalık haber videoları ile \%13'ünü oluşturan 10 dakikadan uzun süren haber videolarında; dosya haber, analiz, canlı yayın, çevrimiçi video konferans, belgesel gibi kategorilerde içeriklere rastlanmıştır.

Ortaya konan sonuçlar 1şığında, ulusal gazetelerin Youtube kanalları üzerinden paylaştıkları haber videolarının temel özelliklerini inceleyerek Youtube’u kullanma biçimlerini ortaya koymayı amaçlayan bu çalışmada; gazetelerin Youtube'da paylaştığı haber videolarının karakteristik özelliklerini televizyon ve haber ajanslarından gelen görüntülerin biçimlendirdiği, gazetelerin Youtube'u TV/ajans haberlerini internete yüklemek için kullandıkları, Youtube'a özel içerik üretmede yetersiz kaldıkları ve dolayısıyla Youtube'un potansiyelini yeterince anlayamadıkları ifade edilebilmektedir.

Birincil hedefi televizyon olan televizyon ve ajans haberlerinin Youtube'da baskın bir şekilde kullanılması, gazetelerin Youtube'u, “televizyon ya da ajansların ürettiği haberlerin internete yüklendiği platform" olarak konumlandırdıkları biçiminde yorumlanabilmektedir. $\mathrm{Bu}$ nedenle, gazetelerin Youtube'a özel içerikler üretme noktasında henüz emekleme aşamasında olduklarını söylemek yanlış olmayacaktır. Özellikle Covid-19 pandemisi gibi tüm dünyayı etkileyen bir olayın sağlık ve eğitim alanlarına yansımaları düşünüldüğünde, bu alanlarda neredeyse hiç dosya haber yapılmaması ve bunun yerine gündem kategorisinde, yaşanan son 
dakika bilgilerine yer verilmesi, gazetelerin Youtube'a özel içerik üretmek yerine televizyon ya da ajansların ürettiği haberleri tercih ettiğini göstermektedir.

Araştırma sonuçları değerlendirildiğinde, gazetelerin Youtube'a özgü içerik üretimini artırmasının gerekli olduğu ifade edilebilmektedir. Bunun için de gazetelerde, video haberciliği ve sosyal medya ile ilgili ayrı birimler oluşturularak bu alanlarda uzmanlaşmış medya profesyonellerinin istihdam edilmesi gerektiğini ifade etmek mümkündür.

Son olarak, dijital dünyanın oyunun kurallarını giderek değiştirdiği ve insanların medya kullanma alışkanlıklarını yeniden biçimlendirdiği düşünüldüğünde, televizyon için hazırlanan içeriklerle Youtube'da kitle elde etmenin sürdürülebilir olmayacağ 1 söylenebilmektedir. Bu nedenle, gazetelerin Youtube'a özgü içerik üretimini artıması, gazetelerin Youtube'un potansiyelini doğru kullanmasını sağlayacak ve dolayısıyla Youtube gazeteciliğinin etki gücünü de artıracaktır.

\section{EXTENDED ABSTRACT}

The aim of this study is to reveal the ways in which national newspapers use YouTube by examining news videos shared on their Youtube channels. Within the scope of the study, a total of 554 videos shared on August 1-31, 2020 by the 5 most viewed national newspapers on YouTube were analyzed by content analysis method.

In line with the main purpose of the study, answers to the following research questions were sought:

1- What kind of news is shared on the Youtube channels of national newspapers?

2- What kind of videos are shared on the Youtube channels of national newspapers?

3- What are the structural features of the videos that national newspapers share on their Youtube channels?

4- What are the content-related features of the videos that national newspapers share on their Youtube channels?

5- What is the duration of the videos shared by national newspapers on Youtube channels?

Research questions are also the subjects of categories determined by the content analysis method. In order to find answers to the main purpose of the study and the research questions put forward to illuminate this main purpose, a literature review on the subject was first conducted. National newspapers published in Turkey entered the internet world with online 
newspapers and news sites in the 1990s. Since the 2000s, with the spread of social media, newspapers have started to share news through social media channels as well as news sites. Since the 2000s to date, social media has been expanding its sphere of influence and increasing its importance as a news medium.

Many social media platforms such as Facebook, Twitter, Instagram and Youtube are among the important channels where newspapers share their news. Among these platforms, Youtube, with the facilities and opportunities it offers and being the most popular social media platform in Turkey, has significant potential for journalism. With news videos shared by citizens and corporate media and live broadcasting feature, the use of Youtube, a popular and effective platform that provides instant news to users, by newspapers is an issue that needs to be addressed.

The realization of the journalism potential of Youtube, which was established in 2005, is due to the amateur news videos produced by the citizens. The fact that events such as natural disasters, accidents, and forensic cases are recorded by citizens on their mobile phones and shared on YouTube has caused amateur news videos to attract more and more attention. Twenty Youtube videos covering the 2011 tsunami disaster in Japan have been viewed nearly 100 million times in the first week following the incident. This event has caused YouTube to be seen as a news medium all over the world.

In this study which aims to reveal how YouTube- a platform that is growing in potential- is used by national newspapers; the following are concluded, most of the videos shared by newspapers consist of television or agency-produced agenda news which are raw footage containing the voice of the news source and the ambient sound, and the duration of the news videos is $1.01-4.00$ minutes long.

Accordingly, looking at the news kinds in shared videos, it seems that almost half of the videos shared by newspapers consist of news in the agenda category. Lesser than the agenda news, the news on politics and life were mostly shared. The least shared types of news are environment, education and science-technology news.

Looking at the types of news videos shared by newspapers, it was found that about $80 \%$ of the videos shared during the one-month period in which the study was conducted consisted of news produced by television or agencies. TV / agency news is followed by file news and 
analysis news, respectively. It has been revealed that citizen-based news is almost never used in the news that newspapers share from Youtube channels. Based on this, it is possible to say that citizen-based news, which is mentioned as the area where YouTube intersects with journalism, is ineffective in the practices of national newspapers using YouTube.

Looking at the structural characteristics of news videos, it was again found that almost $80 \%$ of them consisted of raw footage. Less than the raw footage, edited videos and online video conference recordings were found.

Looking at the content characteristics of news videos, it was seen that in almost half of the shared videos, the voice of the news source and the ambient sound were kept intact. This can be explained as an effect of using raw TV/agency footage in news videos.

Looking at the duration of news videos shared by newspapers, about half of the videos have been observed to be in the 1.01-4.00 minutes range. These durations are the same as those durations of TV/agency news, which accounts for $80 \%$ of all videos.

In the light of the results of the study these can be stated that the general characteristic of the news videos that newspapers share on YouTube is determined by footage from television and news agencies, newspapers position YouTube as a platform where they share television and agency news, they are insufficient to produce YouTube-targeted content and therefore they cannot fully use the potential of an important medium such as Youtube.

The dominant sharing of television and agency news- prepared to be broadcasted on television networks- on YouTube can be interpreted as newspapers' positioning YouTube, as a "platform where news produced by television or agencies is uploaded to the internet". So it would not be wrong to claim that newspapers are still baby-stepping into the area of producing YouTube-targeted content. Especially given the repercussions of an event affecting the entire world, such as the Coronavirus outbreak; instead of making news files in the areas of health and education, the inclusion of breaking news in the agenda category indicates that newspapers prefer to share the news videos produced by tv crews or agencies rather than producing YouTube-targeted content. When the research results are interpreted, it can be stated that newspapers need to increase the production of YouTube-targeted content. For this reason, it is possible to express that separate units related to video journalism and social media should be 
established in newspapers and that media professionals specializing in these areas should be employed.

Finally, given that the digital world has changed the rules of the game and shaped people's habits of using media, it can be said that gaining an audience on YouTube with content prepared for television will not be sustainable. For this reason, the fact that newspapers augment YouTube-targeted content will enable them to use YouTube's potential correctly, and therefore also increase the impact power of YouTube journalism.

\section{KAYNAKÇA}

Alemdar, K., \& Uzun, R. (2019). Herkes için gazetecilik. Ankara: Siyasal Kitabevi.

Alexa. (2020). The top 500 sites on the web. Temmuz 21, 2020 tarihinde Alexa: https://www.alexa.com/topsites adresinden alınd1

Argila, J. (2017). How to create video news that rocks in social media. Ağustos 13, 2020 tarihinde Reuters Institute:

https://reutersinstitute.politics.ox.ac.uk/sites/default/files/2017-

09/Argila\%2C\%20How\%20to\%20create\%20video\%20news\%20that $\% 20$ rocks $\% 20 \mathrm{in}$ $\% 20$ social\%20media.pdf adresinden alındı

Associated Press. (2013). White smoke: the new era for video news in europe. Temmuz 02, 2020 tarihinde Associated Press: https://www.ap.org/research/video-newsinsights/whitesmoke/english.html adresinden alındı

Basın İlan Kurumu. (2020). Yaygın gazeteler. Temmuz 11, 2020 tarihinde Basın İlan Kurumu: https://www.bik.gov.tr/gazeteler/ adresinden alındı

Bock, M. A. (2011). You really, truly, have to "be there": video journalism as a social and material construction. Journalism \& Mass Communication Quarterly, 4(88), 705-718.

Bock, M. A. (2016). Showing versus telling: comparing online video from newspaper and television websites. Journalism, 4(14), 493-510.

Burgess, J., \& Green, J. (2018). Youtube: online video and participatory culture. Cambridge: Polity Press.

Business of Apps. (2020). Youtube revenue and usage statistics. Ağustos 3, 2020 tarihinde Business of Apps: https://www.businessofapps.com/data/youtube-statistics/ adresinden alınd1

Çevikel, T. (2011). Profesyonel haber medyasında yurttaş katılımı: CNN Türk Haberim örneğinde katılımcı gazeteciliğin sınırları. İleti-ş-im Dergisi(14), 55-77. 
Digital Age. (2020). Türkiye internet ekosisteminde yılın trafik şampiyonları. Ağustos 21, 2020 tarihinde Digital Age: https://digitalage.com.tr/turkiye-internet-ekosisteminde-yilintrafik-sampiyonlari/ adresinden alınd 1

Dijk, J. V. (2016). A ̆g toplumu. (Ö. Sakin, Çev.) İstanbul: Kafka Yayınları.

Güzel, M., \& Özmen, K. (2018). Google tekelinde haberciliğin dönüşümü. Akdeniz Üniversitesi Illetişim Fakültesi Dergisi(29), 206-229.

Geray, H. (2014). Toplumsal araştırmalarda nicel ve nitel yöntemlere giriş. Ankara: Siyasal Kitabevi.

Gray, D. (2004). Doing research in the real world. London: Sage Publication.

Haak, V. D., Parks, M., \& Castells, M. (2012). The future of journalism: networked journalism. International Journal of Communication(6), 2923-2938.

Hermida, A. (2012). Social journalism: exploring how social media is shaping journalism. E. Siepera, \& A. Veglis (Dü) içinde, The Handbook of Global Online Journalism (s. 309328). New Jersey: John Wiley\&Sons.

Kaplan, A. M., \& Haenlein, M. (2010). Users of the world unite: the challenges and opportunities of social media. Business Horizons, 1(53), 59-68.

Koşar, E. S. (2015). Bir haber toplama tekniği: video habercilik. Akdeniz Üniveristesi İletişim Fakültesi Dergisi(23), 26-41.

Newman N., Fletcher, R., \& Nielsen , R. (2016). Reuters Institute Digital News Report 2016. 08 12, 2020 tarihinde University of Oxford Reuters Institute: https://reutersinstitute.politics.ox.ac.uk/sites/default/files/research/files/Digital\%2520 News\%2520Report\%25202016.pdf adresinden alınd1

Newman, N., Fletcher, R., Schulz, A., And1, S., \& Nielsen, K. (2020). Reuters Institute digital news report 2020. Temmuz 30, 2020 tarihinde Reuters Institute: https://reutersinstitute.politics.ox.ac.uk/sites/default/files/202006/DNR_2020_FINAL.pdf adresinden alınd1

Pavlik, J. V. (2013). Yeni medya ve gazetecilik. (Ö. Sakin, Çev.) Ankara: Phoenix.

Pavlik, J. V., \& McIntosh, S. (2004). Converging media: a new introduction to mass communication. New York: Oxford University .

Peer, L., \& Ksiazek, T. B. (2011). Youtube and the challenge to journalism. Journalism Studies, 1(12), 45-63.

Pew Research Center. (2012). Youtube \& News. Ağustos 5, 2020 tarihinde Journalism.org: https://www.journalism.org/2012/07/16/youtube-news/ adresinden alınd1

Riffe, D. (2005). Analyzing media message, using quantitative content analysis in research. New Jersey: Lawrence Erlbaum Associates.

Santin, M., \& Monzoncillo, J. M. (2020). The use of Youtube by the spanish press: a model to be defined. El Profesional de la Información, 1(29), 1-14. 
Şen, A. F. (2020). Bir dijital gazetecilik uygulaması olarak video gazeteciliği ve çevrimiçi haber videolar1. Ö. Erkman, B. Ataman, \& B. Çoban (Dü) içinde, Yeni gazetecilik: mecralar, deneyimler, olanaklar (s. 177-214). İstanbul: Kafka Kitap.

Tokgöz, O. (2019). Temel gazetecilik. Ankara: İmge Kitabevi.

We Are Social. (2020). Digital in 2020. Haziran 27, 2020 tarihinde We Are Social: https://wearesocial.com/digital-2020 adresinden alınd1

Ying, H. (2007). Youtube Gerçek Öyküsü. (İ. Şahin, Çev.) İstanbul: Pegasus Yayınları.

Youtube. (t.y.). Basın için Youtube. Temmuz 14, 2020 tarihinde Youtube: https://www.youtube.com/intl/tr/about/press/ adresinden alınd 1 